\title{
PENGARUH TINGKAT PENGETAHUAN AKUNTANSI, BUDAYA ORGANISASI, DAN MOTIVASI BERPRESTASI TERHADAP KINERJA PENGELOLAAN KEUANGAN PADA BADAN PENGELOLAAN KEUANGAN DAN ASET DAERAH KABUPATEN BOGOR PROVINSI JAWA BARAT
}

\author{
Oleh \\ Rahmat Nurhidayatullah Latief ${ }^{1}$, \\ Ngadisah $^{2}$, Marja Sinurat ${ }^{3}$ \\ 1) Program Magister Terapan Studi Pemerintahan Daerah Institut Pemerintahan Dalam Negeri \\ nurhidayatlatif88@gmail.com \\ 2,3) Institut Pemerintahan Dalam Negeri
}

\begin{abstract}
$T$ his research is intended to obtain an overview of the influence of the level of accounting knowledge, organizational culture and achievement motivation on financial management performance at the Regional Financial and Asset Management Agency of Bogor Regency. Meanwhile, the purpose of this study was to determine and analyze (1) The effect of the level of accounting knowledge on financial management performance; (2) The influence of organizational culture on financial management performance; (3) The effect of achievement motivation on financial management performance; (4) The influence of the level of accounting knowledge, organizational culture, and achievement motivation on financial management performance. This research uses a quantitative research approach. Data collection using library research, research instruments. The data analysis technique used linear regression analysis and multiple regression analysis. The conclusions obtained from the research results are as follows: First, the level of accounting knowledge has an effect on financial management performance $(r=0.745)$ and is significant on financial management performance [Sig. (1-tailed) $=0,000]$. Second, organizational culture has an effect on financial management performance $(r=0.449)$ and is significant on financial management performance [Sig. (1-tailed) $=0,000]$. Third, achievement motivation has an effect on financial management performance $(r=0.437)$ and is significant on financial management performance [Sig. (1-tailed)=0,000]. Fourth, the level of accounting knowledge, organizational culture and achievement motivation have an effect on financial management performance ( $R=0.748)$ and are significant on financial management performance (Sig. $=0.000)$.
\end{abstract}

Keywords: level of knowledge in accounting, organizational culture, achievement motivation, performance in financial management

\footnotetext{
Abstrak

Penelitian ini dimaksudkan untuk memperoleh gambaran mengenai pengaruh tingkat pengetahuan akuntansi, budaya organisasi dan motivasi berprestasi terhadap kinerja pengelolaan keuangan pada Badan Pengelolaan Keuangan dan Aset Daerah Kabupaten Bogor. Sedangkan tujuan penelitian ini adalah mengetahui dan menganalisis (1) Pengaruh tingkat pengetahuan akuntansi terhadap kinerja pengelolaan keuangan; (2) Pengaruh budaya organisasi terhadap kinerja pengelolaan keuangan; (3) Pengaruh motivasi berprestasi
} 
terhadap kinerja pengelolaan keuangan; (4) Pengaruh tingkat pengetahuan akuntansi, budaya organisasi, dan motivasi berprestasi terhadap kinerja pengelolaan keuangan. Penelitian menggunakan pendekatan penelitian kuantitatif. Pengumpulan data menggunakan studi kepustakaan, instrumen penelitian. Teknik analisis data menggunakan analisis regresi linier dan analisis regresi ganda. Simpulan yang didapat dari hasil penelitian adalah berikut. Pertama, tingkat pengetahuan akuntansi berpengaruh terhadap kinerja pengelolaan keuangan $(r=0,745)$ dan signifikan terhadap kinerja pengelolaan keuangan [Sig. (1-tailed) = 0,000]. Kedua, budaya organisasi berpengaruh terhadap kinerja pengelolaan keuangan $(r=0,449)$ dan signifikan terhadap kinerja pengelolaan keuangan [Sig. (1-tailed) $=0,000]$. Ketiga, motivasi berprestasi berpengaruh terhadap kinerja pengelolaan keuangan $(r=0,437)$ dan signifikan terhadap kinerja pengelolaan keuangan [Sig. (1-tailed) =0,000]. Keempat, tingkat pengetahuan akuntansi, budaya organisasi dan motivasi berprestasi berpengaruh terhadap kinerja pengelolaan keuangan $(R=0,748)$ dan signifikan terhadap kinerja pengelolaan keuangan (Sig. $=0,000)$.

Kata kunci: tingkat pengetahuan akuntansi, budaya organisasi, motivasi berprestasi, kinerja pengelolaan keuangan

\section{PENDAHULUAN}

$\mathrm{P}$ elaksanaan otonomi daerah tidak hanya dapat dilihat dari seberapa besar daerah akan memperoleh dana perimbangan, tetapi hal tersebut harus diimbangi dengan sejauh mana instrumen atau sistem pengelolaan keuangan daerah mampu memberikan nuansa manajemen keuangan yang lebih adil, rasional, transparan, partisipasif dan bertanggungjawab. Keberhasilan pengelolaan keuangan daerah mempunyai dampak langsung terhadap keberhasilan otonomi daerah dan sumbangan yang besar dalam upaya mewujudkan good governance. Sayangnya dalam upaya untuk mewujudkan akuntabilitas atau pertanggungjawaban yang jelas, terutama dalam pengelolaan keuangan daerah banyak tantangan yang harus dihadapi oleh SKPD, seperti pemahaman aparatur pemerintah daerah terkait akuntansi yang belum maksimal, dan selalu menjadi salah satu kendala teknis dalam pengelolaan dan pelaporan keuangan daerah. Padahal SKPD adalah elemen yang paling berperan dalam pelaksanaan dan penatausahaan APBD.
Maka pemahaman akuntansi dalam hal keuangan daerah tentunya sangat diperlukan oleh aparatur SKPD untuk mempertanggungjawabkan penggunaan serta pengelolaan anggaran SKPD terkait.

\section{Identifikasi Masalah}

Permasalahan yang dapat diidentifikasi dari latar belakang penelitian adalah sebagai berikut.

1. Penurunan opini yang diberikan oleh Badan Pemeriksa Keuangan.

2. Keterlambatan pelaporan pertanggungjawaban keuangan.

3. Kesulitan dalam pembuatan laporan dan pertanggungjawaban keuangan.

4. Penurunan realisasi anggaran pendapatn dan belanja pada tahun 2017.

5. Penurunan realisasi anggaran pendapatn dan belanja pada tahun 2018 .

6. Kinerja pengelolaan keuangan yang menurun pada Badan Pengelolaan Keuangan dan Aset Daerah Kabupaten Bogor. 


\section{Perumusan Masalah}

Berdasarkan latar belakang penelitian dan pembatasan masalah di atas maka dapat dibuat rumusan masalah sebagai berikut.

1. Seberapa besar pengaruh tingkat pengetahuan akuntansi terhadap kinerja pengelolaan keuangan?

2. Seberapa besar pengaruh budaya organisasi terhadap kinerja pengelolaan keuangan?

3. Seberapa besar pengaruh motivasi berprestasi terhadap kinerja pengelolaan keuangan?

4. Seberapa besar pengaruh tingkat pengetahuan tentang akuntansi, budaya organisasi, motivasi berprestasi terhadap kinerja pengelolaan keuangan?

\section{Maksud Penelitian}

Maksud penelitian ini adalah memperoleh gambaran mengenai pengaruh tingkat pengetahuan akuntansi, budaya organisasi dan motivasi berprestasi terhadap kinerja pengelolaan keuangan pada Badan Pengelolaan Keuangan dan Aset Daerah Kabupaten Bogor.

\section{KAJIAN PUSTAKA}

\section{Kinerja Pengelolaan Keuangan}

Kinerja pengelolaan keuangan adalah perilaku kerja pegawai keuangan dalam melaksanakan aktivitasnya pada suatu organisasi untuk mencapai tujuan yang telah ditentukan dengan indikator kompetensi, tanggung jawab dan profesional dalam pelaksanaan kegiatan dan pelaporan anggaran yang tercermin dari hasil pengukuran berupa skor yang diperoleh melalui jawaban responden dari seperangkat kuesioner.

\section{Tingkat Pengetahuan Akuntansi}

Tingkat pengetahuan akuntansi ini meliputi mengelola dan menafsirkan serta pemahaman responden tentang Standar akuntansi Pemerintahan (SAP) sebagai acuan dalam penyelenggaraan akuntansi dan pelaporan keuangan pemerintah. Jenisjenis laporan keuangan pemerintah daerah, fungsi masing-masing laporan keuangan dan komponen yang ada di dalam laporan keuangan Badan Pengelolaan Keuangan dan Aset Daerah Kabupaten Bogor. Selain itu, terdapat pengetahuan deklaratif dan prosedural mengenai akuntansi.

Pengetahuan deklaratif merupakan tentang fakta-fakta dan berdasarkan konsep, contohnya kas merupakan bagian dari aktiva lancar, pengetahuan ini memudahkan dalam analisis rasio. Pengetahuan deklaratif umumnya harus ditempatkan sebelum pengetahuan prosedural, sehingga pengetahuan prosedural dapat disusun melalui menafsirkan pengetahuan deklaratif.

Pengetahuan prosedural merupakan pengetahuan yang konsisten dengan aturan atau langkah-langkah yang diperlukan untuk melakukan tugas secara terampil. Pengetahuan prosedural biasanya tergantung pada pengalaman.

\section{Budaya Organisasi}

Budaya organisasi adalah persepsi seseorang terhadap nilai dan aturan Badan Pengelolaan Keuangan dan Aset Daerah Kabupaten Bogor yang dirasakan oleh anggota organisasi, dengan indikasi adanya kejujuran, kebanggaan, etika, kepatuhan, pedoman/standar, dan struktur dalam pelaksanaan tugas untuk mewujudkan tujuan yang ingin di capai, hubungan kerja sama, partisipasi, inovasi dan penghargaan, yang tercermin dari hasil pengukuran berupa skor yang diperoleh melalui jawaban responden dari seperangkat kuesioner.

\section{Motivasi Berprestasi}

Motivasi berprestasiadalah dorongan yang datang dari dalam diri pegawai keuangan untuk mau dengan sukarela melakukan pekerjaan 
yang menjadi tanggung jawabnya, dengan indikasi pemenuhan kebutuhan, kepuasan dalam bekerja, pengembangan diri dalam menjalankan tugas pembuat komitmen, tugas pembuatan spj, tugas pencairan anggaran, yang tercermin dari hasil pengukuran berupa skor yang diperoleh melalui jawaban responden dari seperangkat kuesioner.

\section{Hipotesis Penelitian}

Berdasarkan kerangka pemikiran di atas dapat diajukan hipotesis penelitian sebagai berikut.

1. Tingkat Pengetahuan Akuntansi berpengaruh terhadap Kinerja Pengelolaan Keuangan Badan Pengelolaan Keuangan dan Aset Daerah Kabupaten Bogor;

2. Budaya Organisasi berpengaruh terhadap Kinerja Pengelolaan Keuangan
Badan Pengelolaan Keuangan dan Aset Daerah Kabupaten Bogor;

3. Motivasi Berprestasi berpengaruh terhadap Kinerja Pengelolaan Keuangan Badan Pengelolaan Keuangan dan Aset Daerah Kabupaten Bogor;

4. Tingkat Pengetahuan Akuntansi, Budaya Organisasi, dan Motivasi Berprestasi berpengaruh terhadap Kinerja Pengelolaan Keuangan Badan Pengelolaan Keuangan dan Aset Daerah Kabupaten Bogor.

\section{KERANGKA PEMIKIRAN}

Kerangka pemikiran adalah "logical construct" atau kerangka logika dalam menggambarkan fenomena atau variabel yang akan diteliti, ditampilkan dalam bentuk bagan alur pemikiran berikut.

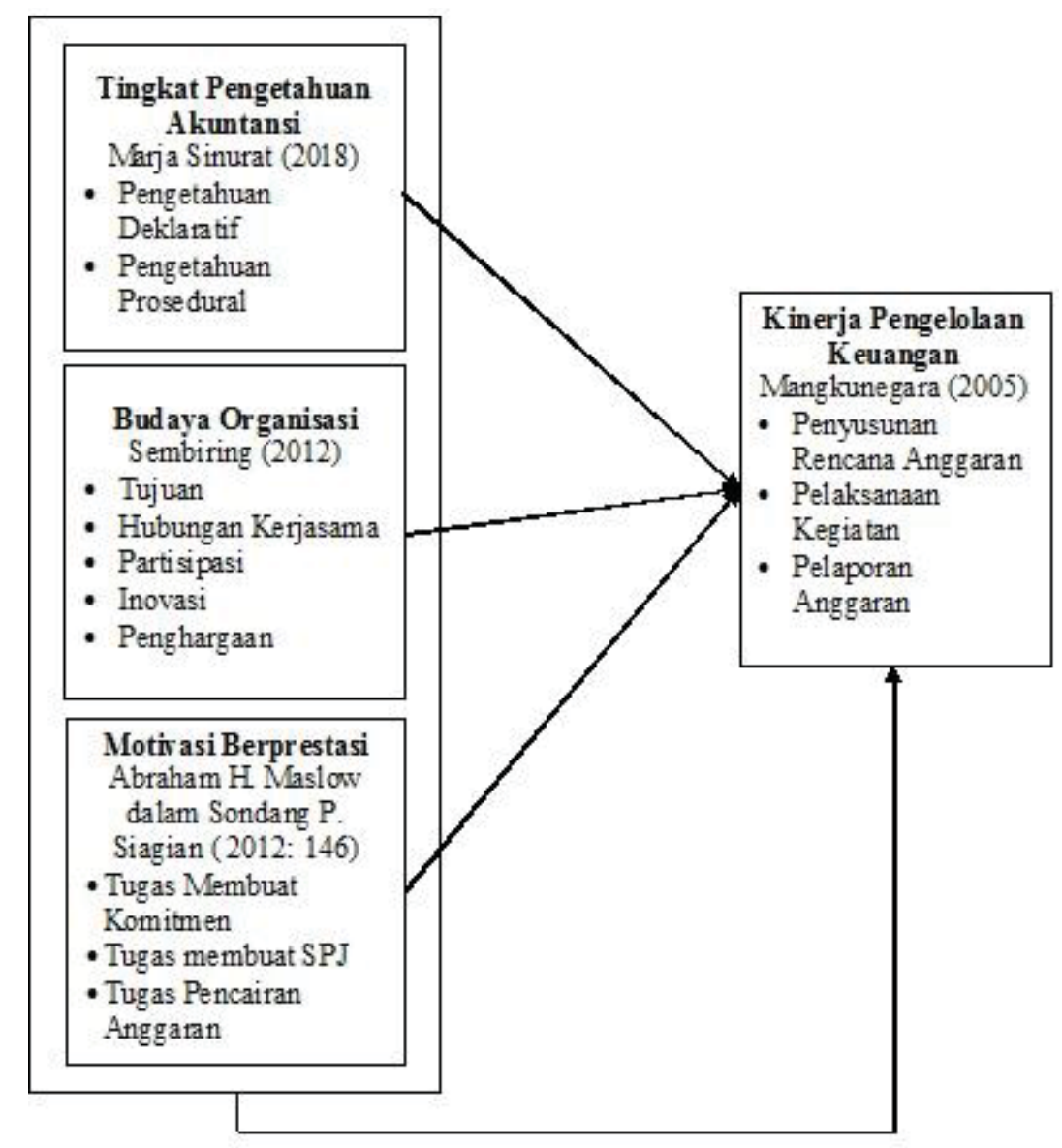

Sumber: Penulis, 2019 


\section{METODE PENELITIAN}

Penulis menggunakan pendekatan kuantitatif melalui analisis deskriptif metode eksplanatori. Desain yang peneliti gunakan adalah analisis deskriptif, suatu metode yang digunakan untuk menemukan pengetahuan yang seluas-luasnya terhadap objek penelitian pada suatu saat yang ditentukan hubungan antar variabel dengan menganalisis numerik (angka) menggunakan metode statistik inferensial melalui pengujian hipotesis serta melakukan interpretasi secara mendalam terkait apa yang dilakukan pada penelaahan pengaruh tingkat pengetahuan akuntansi, budaya organisasi, dan motivasi berprestasi $\left(\mathrm{X}_{1}, \mathrm{X}_{2}\right.$, $\mathrm{X}_{3}$ ) terhadap kinerja pengelolaan keuangan (Y) pada Badan Pengelolaan dan Aset Daerah (BPKAD) Kabupaten Bogor. Unit analisis dalam penelitian ini adalah Badan Pengelolaan Keuangan dan Aset Daerah Kabupaten Bogor. Populasi penelitian adalah seluruh pegawai Badan Pengelolaan Keuangan dan Aset Daerah Kabupaten Bogor. Total populasi sebanyak 92 pegawai. Sampel penelitian ini adalah 92 orang pegawai BPKAD Kabupaten Bogor.

Teknik pengumpulan data untuk pendekatan kuantitatif terutama adalah kuesioner atau angket dan dokumentasi atau studi kepustakaan. Informasi dan data didapatkan melalui instrumen penelitian berupa kuesioner. Informasi dan data dari kuesioner menggunakan skala Likert untuk diketahui bobot nilainya, yaitu variabel tingkat pengetahuan akuntansi, budaya organisasi, motivasi berprestasi, dan kinerja pengelolaan keuangan.

Teknik analisis yang digunakan adalah analisis regresi, analisis regresi sangat bermanfaat untuk melihat pengaruh dari berbagai variabel terhadap variabel lainnya. Teknik lainnya adalah asumsi klasik, oleh karena pada dasarnya asumsi klasik merupakan salah satu uji yang digunakan untuk persyaratan statistik. Hal ini harus dipenuhi hanya pada analisis regresi linier berganda dan tidak pada regresi linier sederhana. Uji hipotesis yang digunakan adalah Uji-F (uji serentak), Uji-F (uji serentak) digunakan untuk menguji apakah secara bersama-sama tingkat pengetahuan akuntansi, budaya organisasi, motivasi berprestasi $\left(\mathrm{X}_{1}, \mathrm{X}_{2}, \mathrm{X}_{3}\right)$ mempunyai pengaruh terhadap kinerja pengelolaan keuangan $(\mathrm{Y})$.

\section{HASIL PENELITIAN DAN PEMBAHASAN}

Analisis Pengaruh Tingkat Pengetahuan Akuntansi, Budaya Organisasi dan Motivasi Berprestasi terhadap Kinerja Pengelolaan Keuangan Pada Badan Pengelolaan Keuangan dan Aset Daerah Kabupaten Bogor diperoleh hasil sebagai berikut.

\section{Pengaruh Tingkat Pengetahuan Akuntansi $\left(\mathrm{X}_{1}\right)$ terhadap Kinerja Pengelolaan Keuangan (Y)}

Nilai $r$ sebesar 0,745 menunjukkan bahwa korelasi antara Tingkat Pengetahuan Akuntansi $\left(\mathrm{X}_{1}\right)$ dengan Kinerja Pengelolaan Keuangan (Y) adalah kuat karena di antara 0,60-0,799. r Square atau koefisien determinasi adalah 0,555 artinya 55,5\% tingkat pengetahuan akuntansi memberikan kontribusi terhadap kinerja pengelolaan keuangan. Nilai $t_{\text {hitung }}>t_{\text {tabel }}$ atau 9,067 $>2,000$ maka $\mathrm{H}_{0}$ ditolak dan $\mathrm{H}_{a}$ diterima, artinya signifikan. tingkat pengetahuan akuntansi mempunyai pengaruh signifikan terhadap kinerja pengelolaan keuangan.

Nilai Sig. (1-tailed) variabel tingkat pengetahuan akuntansi dan kinerja pengelolaan keuangan adalah 0,000 dibandingkan dengan probabilitas 0,05 ternyata nilai probabilitas 0,05 lebih besar dari nilai probabilitas Sig. (1-tailed) atau $[0,05>0,000]$, maka $\mathrm{H}_{0}$ ditolak dan $\mathrm{H}_{\mathrm{a}}$ diterima yang artinya signifikan. Terbukti bahwa tingkat pengetahuan akuntansi mempunyai pengaruh signifikan terhadap kinerja pengelolaan keuangan. 


\section{Pengaruh Budaya Organisasi terhadap Kinerja Pengelolaan Keuangan}

r Square atau koefisien determinasi adalah 0,202 artinya $20,2 \%$ budaya organisasi memberikan kontribusi terhadap kinerja pengelolaan keuangan. Sedangkan sisanya $79,8 \%$ dipengaruhi oleh variabel lain di luar budaya organisasi. Nilai $t_{\text {hitung }}>t_{\text {tabel }}$ atau 4,769>2,000 maka $\mathrm{H}_{0}$ ditolak dan $\mathrm{H}_{\mathrm{a}}$ diterima, artinya signifikan. Budaya organisasi berpengaruh signifikan terhadap kinerja pengelolaan keuangan. Nilai Sig. (1-tailed) variabel budaya organisasi dan kinerja pengelolaan keuangan adalah 0,000 dibandingkan dengan probabilitas 0,05 ternyata nilai probabilitas 0,05 lebih besar dari nilai probabilitas Sig. (1-tailed) atau [0,05 > 0,000], maka $\mathrm{H}_{0}$ ditolak dan $\mathrm{H}_{\mathrm{a}}$ diterima yang artinya signifikan. Terbukti bahwa budaya organisasi mempunyai pengaruh signifikan terhadap kinerja pengelolaan keuangan.

\section{Pengaruh Motivasi Berprestasi terhadap Kinerja Pengelolaan Keuangan}

Motivasi berprestasi memberikan kontribusi $19,1 \%$ terhadap kinerja pengelolaan keuangan. Sedangkan sisanya 80,9\% dipengaruhi oleh variabel lain di luar motivasi berprestasi. Nilai $t_{\text {hitung }}>t_{\text {tabel }}$ atau 4,609 > 2,000 maka $\mathrm{H}_{0}$ ditolak dan $\mathrm{H}_{\mathrm{a}}$ diterima, artinya signifikan. Motivasi berprestasi berpengaruh signifikan terhadap kinerja pengelolaan keuangan.

Nilai Sig. (1-tailed) variabel motivasi berprestasi dan kinerja pengelolaan keuangan adalah 0,000 dibandingkan dengan probabilitas 0,05 ternyata nilai probabilitas 0,05 lebih besar dari nilai probabilitas Sig. (1-tailed) atau [0,05 > 0,000], maka $\mathrm{H}_{0}$ ditolak dan $\mathrm{H}_{\mathrm{a}}$ diterima yang artinya signifikan. Terbukti bahwa motivasi berprestasi mempunyai pengaruh signifikan terhadap kinerja pengelolaan keuangan.
Pengaruh Tingkat Pengetahuan Akuntansi, Budaya Organisasi, dan Motivasi Berprestasi terhadap Kinerja Pengelolaan Keuangan

Nilai R sebesar 0,748 dan $\mathrm{R}^{2}$ (R Square) atau koefisien determinasi adalah 0,559 artinya 55,9\%tingkatpengetahuanakuntansi, budaya organisasi dan motivasi berprestasi memberikan kontribusi terhadap kinerja pengelolaan keuangan. Sedangkan sisanya $44,1 \%$ dipengaruhi oleh variabel lain di luar tingkat pengetahuan akuntansi, budaya organisasi dan motivasi berprestasi. Nilai Sig. variabel Tingkat Pengetahuan Akuntansi, Budaya Organisasi dan Motivasi Berprestasi dengan Kinerja Pengelolaan Keuangan adalah sebesar 0,000, dibandingkan dengan probabilitas 0,05 ternyata nilai probabilitas 0,05 lebih besar dari nilai probabilitas Sig. atau $[0,05>0,000]$, maka $\mathrm{H}_{0}$ ditolak dan $\mathrm{H}_{\mathrm{a}}$ diterima yang artinya signifikan. Terbukti bahwa Tingkat Pengetahuan Akuntansi, Budaya Organisasi dan Motivasi Berprestasi mempunyai pengaruh signifikan terhadap kinerja pengelolaan keuangan.

\section{SIMPULAN}

1. Tingkat Pengetahuan Akuntansi berpengaruh terhadap Kinerja Pengelolaan Keuangan ( $r=0,745)$ dan signifikan terhadap Kinerja Pengelolaan Keuangan [Sig. (1-tailed) $=0,000]$. Selain itu, kontribusi tingkat pengetahuan akuntansi terhadap kinerja pengelolaan keuangan adalah sebesar 55,5\% dan sisanya sebesar $44,5 \%$ dipengaruhi oleh variabel lain di luar tingkat pengetahuan akuntansi.

2. Budaya Organisasi berpengaruh terhadap Kinerja Pengelolaan Keuangan $(r=0,449)$ dan signifikan terhadap Kinerja Pengelolaan Keuangan [Sig. $(1$-tailed $)=0,000]$. Adapun budaya organisasi memberikan kontribusi terhadap kinerja pengelolaan keuangan adalah sebesar $20,2 \%$ dan sisanya 
$79,8 \%$ dipengaruhi oleh variabel lain di luar budaya organisasi.

3. Motivasi Berprestasi berpengaruh terhadap Kinerja Pengelolaan Keuangan $(r=0,437)$ dan signifikan terhadap Kinerja Pengelolaan Keuangan [Sig. (1-tailed $)=0,000]$. Selanjutnya kontribusi motivasi berprestrasi terhadap kinerja pengelolaan keuangan adalah sebesar $19,1 \%$ dan sisanya $80,9 \%$ dipengaruhi oleh variabel lain di luar motivasi berprestasi.

4. Tingkat Pengetahuan Akuntansi, Budaya Organisasi dan Motivasi Berprestasi berpengaruh terhadap Kinerja Pengelolaan Keuangan $(R=0,748)$ dan signifikan terhadap Kinerja Pengelolaan Keuangan (Sig. $=0,000)$. Kontribusi terhadap kinerja pengelolaan keuangan dari tingkat pengetahuan akuntansi, budaya organisasi dan motivasi berprestasi adalah 55,9\% dan sisanya $44,1 \%$ dipengaruhi oleh variabel lain di luar tingkat pengetahuan akuntansi, budaya organisasi dan motivasi berprestasi.

\section{SARAN}

Ketelitian pegawai dalam menyusun rencana anggaran perlu dipertahankan mengingat kapasitas keuangan daerah pada dasarnya menempatkan sejauh mana pemerintah daerah mampu mengoptimalkan penerimaan dan pendapatan daerah. Berbagai objek penerimaan daerah dianalisis untuk memahami perilaku atau karakteristik penerimaan daerah selama ini. Analisis keuangan dibuat untuk mengidentifikasi berbagai proyeksi pendapatan daerah. Analisis dilakukan untuk memperoleh gambaran umum kapasitas pendapatan daerah dengan proyeksi lima tahun ke depan untuk perhitungan kerangka pendanaan pembangunan daerah. Oleh karena itu, pegawai harus ahli dalam pelaksanaan kegiatan pengelolaan keuangan dimaksud.

\section{DAFTAR PUSTAKA}

Atkinson, J., 1982, Motivation and Achievement, V.H. Winston and Sons, Washington, D.C.

Danim Sudarmawan, 2004, Motivasi Kepemimpinan dan Efektivitas Kelompok, Rineka Cipta, Jakarta.

Darise, Nurlan, 2008, Akuntansi Keuangan Daerah (Akuntansi Sektor Publik), Indeks, Jakarta.

Heckhausen, H., 1967, The Anatomy of Achievement Motivation, Academic Press, New York.

Ishak, 2003, Manajemen Motivasi, Gramedia, Jakarta.

John W. Creswell, 2016, Research Design Pendekatan Metode Kualitatif, Kuantitatif, dan Campuran Edisi Keempat, Pustaka Pelajar, Yogyakarta.

Lukman, Sampara, 2016, Pedoman Penulisan Usulan Penelitian dan Tesis Program Studi Magister Administrasi Pemerintahan Daerah, Program Pascasarjana IPDN, Jatinangor.

Mangkunegara, Anwar Prabu, 2005, Evaluasi Kinerja Sumber Daya Manusia, Refika Aditama, Jakarta.

McClelland, D.C., 1975, The Achievement Motivation, Irvington, New York.

McClelland, D.C., 1987, Human Motivation, The Press Syndicate of The University of Chambrige, New York.

Pabundu, Mohammad, 2006, Budaya Organisasi dan Peningkatan Kinerja Perusahaan, Bumi Aksara, Jakarta.

Riduwan, dan Sunarto, 2011, Pengantar Statistika untuk Penelitian Pendidikan, Sosial, Ekonomi, Komunikasi, dan Bisnis, Alfabeta, Bandung.

Siagian, S.P., 2002, Kiat Meningkatkan Produktivitas Kerja, Rineka Cipta, Jakarta.

S.P., 2004, Teori Motivasi dan Aplikasinya, Rineka Cipta, Jakarta.

S.P., 2012, Teori Motivasi dan Aplikasinya, Rineka Cipta, Jakarta.

Simanjuntak, Payaman, 2005, Manajemen dan Evaluasi Kinerja, FE UI, Jakarta. 
Sinurat, Marja, 2018, Akuntansi Keuangan Daerah, Penerbit: Ghalia Indonesia, Bogor.

Sinurat, Marja dan Horas Murits Panjaitan, 2017, Perencanaan dan Penganggaran Daerah, Pustaka Rahmat, Bandung.

Sembiring, Masana, 2012, Budaya dan Kinerja Organisasi (Perspektif Organisasi Pemerintah), Fokusmedia, Bandung.

Sofyandi dan Garniwa, 2007, Perilaku Organisasi, Graha Ilmu, Yogyakarta.

Soleh, Chabib. dan Suripto, 2011, Menilai Kinerja Pemerintahan Daerah, Fokusmedia, Bandung.

Suastha, T. Nyoman, 2006, Evaluasi Kinerja dan Manajemen Sumber Daya Manusia, Universitas Indonusa Esa Unggul, Jakarta.

Sudarwan, Danim, 2004, Motivasi Kepemimpinan dan Efektivitas Kelompok, Rineka Cipta, Jakarta.

Sudjana, 2009, Metode Statistika, Tarsito, Bandung.

Sugiyono, 2017, Statistika untuk Penelitian, Alfabeta, Bandung.

Wibowo, 2004, Manajemen Kinerja, Raja Grafindo, Jakarta.

Widarto Rachbini, dkk, 2018, Statistika Terapan Cara Mudah dan Cepat Menganalisis Data, Mitra Wacana Media, Jakarta.

Winardi, 2001, Motivasi dan Pemotivasian dalam Organisasi, Grafindo, Jakarta.

\section{Peraturan Perundang-Undangan}

Undang-Undang Nomor 33 Tahun 2004 tentang Perimbangan Keuangan antara Pemerintah Pusat dan Pemerintahan Daerah.

Peraturan Pemerintah Nomor 71 Tahun 2010 tentang Standar Akuntansi Pemerintahan.

Peraturan Menteri Dalam Negeri Nomor 64 Tahun 2013 tentang Penerapan Standar Akuntansi Pemerintahan Berbasis Akrual pada Pemerintah Daerah.

\section{Skripsi, Tesis dan Disertasi}

Listiani, Wirna, 2010, Pengaruh Pengetahuan Akuntansi, Pengetahuan Auditing dan
Kemampuan Menyelesaikan Masalah terhadap Pertimbangan Anggota Komite Audit (Studi Empiris terhadap Anggota Komite Audit pada Perbankan Di Pekanbaru), Skripsi ini tidak dipublikasikan Universitas Islam Negeri Sultan Syarif Kasim Pekanbaru.

Santosa, Dori, 2019, Pengaruh Kompetensi, Profesionalisme dan Kapasitas Kelembagaan terhadap Kinerja Auditorat Utama Keuangan Negara VI Badan Pemeriksaan Keuangan, Disertasi ini tidak dipublikasikan Institut Pemerintahan Dalam Negeri Jatinangor.

Tambunan, David Rolan, 2016, Pengaruh Kompetensi, Motivasi dan Komitmen Organisasi terhadap Kinerja Pengelolaan Keuangan Satuan Kerja Perangkat Daerah Pemerintahan Kabupaten Tapabuli Utara Melalui Implementasi SIMDA, Tesis ini tidak dipublikasikan Universitas Sumatera Utara Medan.

Jurnal

Rafar, Tari Mellisa, dkk, 2015, Pengaruh Kompetensi Pengelolaan Keuangan dan Akuntabilitas terhadap Kinerja Pengelolaan Keuangan Daerah (Studi pada Satuan Kerja Perangkat Daerah Pemerintah Kabupaten Aceh Utara), Jurnal Magister Akuntansi Pascasarjana Universitas Syiah Kuala, Vol 4 (2), 64-71.

Sinurat, Marja, 2017, Pengaruh Kesiapan Sumber Daya Aparatur dan Persepsi Pemerintah Daerah terhadap Penerapan Akuntansi Berbasis Akrual (Studi Kasus pada Pemerintah Daerah Kabupaten Tasikmalaya Provinsi Jawa Barat, 2016), JE \& KP (Jurnal Ekonomi dan Keuangan Publik), Vol 4 (1), 67-86.

\section{Website Internet}

https://bogorkab.go.id/pages...

http://bpkad.bogorkab.go.id/kontinuitas-wtppada-tahun-2017/

http://johan-nesh.blogspot.com/2013/06/caramenumbuhkan-motivasi-berprestasi. html?m=1

http: / / s e putarpengertian.blogs pot. 
com/2017/03/pengertian-motivasiberprestasi-serta-ciri-faktornya. html?m=1

h t t p : / / wahyoenoegroho.blogs pot. co.id/2013/04/akuntansi-keuangandaerah.html. h t t p : / / w w w.b p k p.go.id / b e r i t a / $\mathrm{read} / 3065 / 6155 /$ Panel Diskusi Tangangan dan Permasalahan Pengelolaan Keuangan Daerah.bpkp

http://www.statistikian.com/2013/02/tutorialuji-validitas-dengan-spss.html?amp 